\title{
Cholinergic Receptor-Mediated Phosphorylation and Activation of Tyrosine Hydroxylase in Cultured Bovine Adrenal Chromaffin Cells
}

\author{
Susan L. Pocotte, Ronald W. Holz, and *'Tetsufumi Ueda \\ Departments of Pharmacology and *The Mental Health Research Institute, University of Michigan Medical School, \\ Ann Arbor, Michigan, U.S.A.
}

\begin{abstract}
We have identified a 56-kilodalton protein in cultured bovine adrenal chromaffin cells that is phosphorylated when catecholamine secretion is stimulated. Immunodetection on Western blots from both one- and two-dimensional polyacrylamide gels indicated that this protein was tyrosine hydroxylase, the rate-limiting enzyme in catecholamine biosynthesis. Two-dimensional polyacrylamide gel electrophoresis of proteins from unstimulated cells revealed small amounts of phosphorylated protein with a molecular weight of $56 \mathrm{~K}$ and $\mathrm{pI}$ values of 6.37 and 6.27 which were subunits of tyrosine hydroxylase. Nicotinic stimulation of chromaffin cells caused the phosphorylation of three proteins of 56 kilodaltons with $\mathrm{pI}$ values of approximately $6.37,6.27$, and 6.15 which were tyrosine hydroxylase. The immunochemical analysis also revealed that there was unphosphorylated tyrosine hydroxylase 56 kilodaltons with a pI of 6.5 which may have decreased on nicotinic stimulation. The phosphorylation of tyrosine hydroxylase was associated with an increase in in situ conversion of $\left[{ }^{3} \mathrm{H}\right]$ tyrosine to $\left[{ }^{3} \mathrm{H}\right]$ dihydroxyphenylalanine $\left(\left[{ }^{3} \mathrm{H}\right] \mathrm{DOPA}\right)$. Muscarinic stimulation also caused phosphorylation of tyrosine hydroxylase, but to a smaller extent than did nicotinic stimulation. The secretagogues, elevated $\mathrm{K}^{+}$ and $\mathrm{Ba}^{2+}$, stimulated phosphorylation of tyrosine hydroxylase and $\left.{ }^{3} \mathrm{H}\right] D O P A$ production. The effects of nicotinic stimulation and elevated $\mathrm{K}^{+}$on tyrosine hydrox-
\end{abstract}

ylase phosphorylation and $\left[{ }^{3} \mathrm{H}\right] D O P A$ production were $\mathrm{Ca}^{2+}$-dependent. Nicotinic agonists also raised cyclic AMP levels in chromaffin cells after $2 \mathrm{~min}$. Dibutyryl cyclic AMP and forskolin, which have little effect on catecholamine secretion, also caused phosphorylation of tyrosine hydroxylase. These stimulators of cyclic AMP-dependent processes caused the appearance of two phosphorylated subunits of tyrosine hydroxylase with pl values of 6.37 and 6.27 . There was also a small amount of phosphorylated subunit with a pI of 6.15. Both agents stimulated $\left[{ }^{3} \mathrm{H}\right]$ DOPA production. The experiments indicate that tyrosine hydroxylase is phosphorylated and activated when chromaffin cells are stimulated to secrete. The data suggest that the earliest phosphorylation of tyrosine hydroxylase induced by a nicotinic agonist occurs through stimulation of a $\mathrm{Ca}^{2+}$-dependent protein kinase. After 2 min phosphorylation by a cyclic AMP-dependent protein kinase may also occur. Phosphorylation of tyrosine hydroxylase is associated with an increase in in situ tyrosine hydroxylase activity. Key Words: Tyrosine hydroxylase-Cholinergic receptor-3,4-Dihydroxyphenylalanine-Cyclic AMP-Phosphorylation-Bovine adrenal chromaffin cells. Pocotte S. L. et al. Cholinergic receptor-mediated phosphorylation and activation of tyrosine hydroxylase in cultured bovine adrenal chromaffin cells. J. Neurochem. 46, 610-622 (1986).
In the course of studies designed to investigate the possible role of protein phosphorylation in exocytosis of catecholamines from monolayer cultures of bovine adrenal chromaffin cells, we discovered that a 56-kilodalton protein was phosphorylated when the cells were stimulated by a variety of secretagogues (Holz et al., 1980). Amy and Kirshner (1981) observed that a 60-kilodalton protein was phosphorylated under similar conditions. While this work was in progress, Waymire and colleagues demonstrated that acetylcholine stimulated in situ phosphorylation and activation of tyrosine
Received April 29, 1985; accepted August 30, 1985.

Address correspondence to Dr. R. W. Holz at Department of Pharmacology, University of Michigan Medical School, Ann Arbor, MI 48109-0010, U.S.A.

Abbreviations used: DMPP, 1,1-dimethyl-4-phenylpipera- zinium; DOPA, 3,4-dihydroxyphenylalanine; HEPES, $N$-2-hydroxyethylpiperazine- $N^{\prime}$-2-ethanesulfonic acid; PAGE, polyacrylamide gel electrophoresis; PSS, physiological salt solution; SDS, sodium dodecyl sulfate. 
hydroxylase (subunit molecular weight 60 kilodaltons) in suspended bovine adrenal chromaffin cells (Meligeni et al., 1982).

Tyrosine hydroxylase is the rate-limiting step in catecholamine biosynthesis (Nagatsu et al., 1964). Studies with purified bovine striatal tyrosine hydroxylase (Raese et al., 1977), purified rat pheochromocytoma tyrosine hydroxylase (Vulliet et al., 1980), partially purified rat caudate nucleus tyrosine hydroxylase (Joh et al., 1978), and purified bovine adrenal tyrosine hydroxylase (Yamauchi and Fujisawa, 1979) have demonstrated that cyclic AMPdependent protein kinase phosphorylates and activates tyrosine hydroxylase. $\mathrm{A} \mathrm{Ca}^{2+}$, calmodulindependent protein kinase phosphorylates purified rat pheochromocytoma tyrosine hydroxylase (Vulliet et al., 1984) and purified bovine adrenal tyrosine hydroxylase. $\mathrm{Ca}^{2+}$ calmodulin-dependent protein phosphorylation results in enhanced tyrosine hydroxylase activity in the presence of an activator protein (Yamauchi et al., 1981). In situ secretagogue-induced activation of tyrosine hydroxylase has been observed in a variety of tissues including guinea pig vas deferens (Cloutier and Weiner, 1973), rat pheochromocytoma (Chalfie et al., 1977), rat superior cervical ganglion (Horwitz and Perlman, 1984), and bovine adrenal medulla (Haycock et al., 1982a). In both pheochromocytoma cells (Yanagihara et al., 1983; Vulliet et al., 1984) and adrenal medullary chromaffin cells (Meligeni et al., 1982) there is evidence for both $\mathrm{Ca}^{2+}$-dependent and cyclic AMP-dependent phosphorylation and activation of tyrosine hydroxylase.

In this study we have identified the 56-kilodalton protein as tyrosine hydroxylase using immunological techniques and have resolved multiple subunits of phosphorylated tyrosine hydroxylase. We have examined the cholinergic pharmacology of in situ tyrosine hydroxylase phosphorylation and activation and the effects of the noncholinergic secretagogues elevated $\mathrm{K}^{+}$and $\mathrm{Ba}^{2+}$. The data indicate that under a variety of conditions, tyrosine hydroxylase can be phosphorylated by calcium-dependent and cyclic AMP-dependent protein kinases. The phosphorylation is associated with an increase in in situ tyrosine hydroxylase activity.

\section{MATERIALS AND METHODS}

\section{Cell preparation and catecholamine secretion}

Primary dissociated cells from bovine adrenal medulla were prepared and maintained as monolayer cultures in Eagle's minimal essential medium (GIBCO, Grand Island, NY, U.S.A.) containing $10 \%$ heat-inactivated fetal calf serum as previously described (Holz et al., 1982). The culture medium contained $100 \mathrm{U} / \mathrm{ml}$ of penicillin, 100 $\mu \mathrm{g} / \mathrm{ml}$ of streptomycin, $50 \mu \mathrm{g} / \mathrm{ml}$ of gentamycin, and 1.3 $\mu \mathrm{g} / \mathrm{ml}$ of Fungizone (Squibb, Princeton, NJ, U.S.A.) to prevent bacterial and fungal contamination. The culture medium also contained $10 \mu M$ cytosine arabinoside to inhibit fibroblast growth. Cells were usually cultured as monolayers in 16-mm diameter plastic culture wells (Costar, Cambridge, MA, U.S.A.) at a density of 250,000 cells $/ \mathrm{cm}^{2}$. In some experiments cells were plated in 35$\mathrm{mm}$ diameter dishes or 60-mm dishes (Costar) at a density of 250,000 cells $/ \mathrm{cm}^{2}$, or in $6.4-\mathrm{mm}$ diameter wells (Costar) at a density of 500,000 cells $/ \mathrm{cm}^{2}$. Experiments were performed 4-14 days after preparation. There were approximately $\mathbf{4 0} \mathrm{nmol}$ of catecholamine/million cells. Immediately before an experiment, cells were incubated for $1 \mathrm{~h}$ with physiological salt solution (PSS) containing $145 \mathrm{mM}$ $\mathrm{NaCl}, 5.6 \mathrm{mM} \mathrm{KCl}, 2.2 \mathrm{mM} \mathrm{CaCl}_{2}, 0.5 \mathrm{mM} \mathrm{MgCl}_{2}, 5.6$ $\mathrm{m} M$ glucose, $15 \mathrm{~m} M N$-2-hydroxyethylpiperazine- $N^{\prime}-2-$ ethanesulfonic acid (HEPES) (pH 7.4), and $0.5 \mathrm{mM}$ sodium ascorbate unless otherwise indicated. In some experiments PSS was modified to contain $95 \mathrm{mM} \mathrm{NaCl}$ and $56.0 \mathrm{mM} \mathrm{KCl}$. An experiment was initiated by replacing the medium with new solution. All experiments were performed at $25^{\circ} \mathrm{C}$.

Endogenous catecholamines were measured by a fluorescent assay as previously described (Holz et al., 1982). Secretion was expressed as the fraction or percentage of the total cellular catecholamine released into the medium.

\section{Protein phosphorylation}

Intracellular phosphorylation in cells was determined by incubation of cells in $6.4-\mathrm{mm}$ or $16-\mathrm{mm}$ diameter wells for $30 \mathrm{~min}$ in PSS containing ${ }^{32}$ PJphosphate $(0.25-0.5$ $\mathrm{mCi} / \mathrm{ml}$, carrier-free). Cells were subsequently incubated in [ ${ }^{32}$ P)phosphate-free PSS containing various drugs unless otherwise indicated. In some experiments there was a 10-min incubation in [ $\left.{ }^{32} \mathrm{P}\right]$ phosphate-free PSS before addition of solutions with or without drugs. Experiments were usually terminated by replacing the medium with $0.10 \mathrm{ml}-0.25 \mathrm{ml}$ stop solution [3\% sodium dodecyl sulfate (SDS); $2 \%$ mercaptoethanol; $5 \%$ glycerol; $62 \mathrm{mM}$ Tris-Cl. pH 6.7; and $0.5 \mathrm{mg} / \mathrm{ml}$ of bromphenol blue]. Cellular proteins were further denatured by incubation at $90^{\circ} \mathrm{C}$ for 3 $\mathrm{min}$. An aliquot $(0.08 \mathrm{ml})$ was analyzed for phosphoprotein by SDS polyacrylamide (6.9\% or $5-20 \%$ gradient) slab gel electrophoresis (PAGE) and subsequent autoradiography (Ueda and Greengard, 1977). For two-dimensional electrophoresis, incubations in 6.4-mm diameter wells were terminated by addition of $0.03 \mathrm{ml}$ of a solution containing $9.5 \mathrm{M}$ urea, $2 \%$ Nonidet $\mathrm{P}-40,5 \% \beta$-mercaptoethanol, and $2 \%$ Ampholines (pH 3.5-10) to wells. Aliquots $(0.015 \mathrm{ml})$ were subjected to isoelectric focusing followed by SDS, $5-20 \%$ gradient polyacrylamide gel electrophoresis according to O'Farrell (1975). Isoelectric focusing was performed using $11.5-\mathrm{cm}$ tube gels of 2.3 $\mathrm{mm}$ diameter. After isoelectric focusing the $\mathrm{pH}$ values in $0.5-\mathrm{cm}$ segments of a gel were estimated by adding the segments to test tubes, adding 2 ml degassed, deionized water, capping the test tubes, and vortexing briefly. After $2 \mathrm{~h}$ the test tubes were again vortexed and the $\mathrm{pH}$ values measured.

Molecular weights were determined by comparison with the electrophoretic mobilities of standard proteins (Bio-Rad, Richmond, CA, U.S.A.), which were visualized by Coomassie Blue staining. Quantitation of phosphorylation was performed by densitometry of autoradiograms of one-dimensional SDS.PAGE using an EC910 Densitometer (EC-Apparatus, St. Petersburg, FL, U.S.A.). Peak heights (in arbitrary units) on densitometric tracings were measured after subtracting background densities in neighboring regions of the tracing, as described previously (Ueda et al., 1973). The quantitation 
was performed over a range where the densities increased proportionally with the amount of phosphorylated protein. On two-dimensional gels, the only protein at 56 kilodaltons that responded to secretagogues was tyrosine hydroxylase although there were other phosphoproteins of similar molecular weight. Therefore, quantitation of one-dimensional gels may somewhat underestimate the relative increase in tyrosine hydroxylase phosphorylation.

\section{Electrophoretic transfer to nitrocellulose paper and immunochemical detection of tyrosine hydroxylase}

SDS-polyacrylamide gels (6.9\% resolving gels) of $\left.{ }^{32} \mathrm{P}\right]$ proteins or unlabeled proteins were incubated in 20 $\mathrm{m} M$ Tris base, $150 \mathrm{mM}$ glycine, and $20 \%$ methanol (buffer A) for $15 \mathrm{~min}$. The proteins were then transferred electrophoretically to nitrocellulose paper (Millipore, Bedford, MS, U.S.A.) with a Savant Instrument slab gel destainer in buffer $A(60 \mathrm{~V}, 0.22 \mathrm{~A}, 3 \mathrm{~h}$ ) (Towbin et al., 1979; Wilson et al., 1982). The resulting blots were rinsed in distilled water and incubated overnight in $20 \mathrm{ml}$ of 10 $\mathrm{m} M$ Tris- $\mathrm{HCl}, \mathrm{pH} 7.4 ; 154 \mathrm{mM} \mathrm{NaCl} ; 3 \% \mathrm{wt} / \mathrm{vol}$ bovine serum albumin; and $0.02 \%$ sodium azide (buffer $B$ ) at room temperature with gentle shaking. The tyrosine hydroxylase was identified by immunochemical detection with rabbit antiserum against rat pheochromocytoma tyrosine hydroxylase. The antiserum was a generous gift from Dr. A. W. Tank (Department of Pharmacology, University of Colorado School of Medicine, Denver, CO, U.S.A.). The blot incubated with gentle shaking for $4 \mathrm{~h}$ at room temperature with $20 \mathrm{ml}$ of buffer B containing 30 $\mu l$ of antiserum. The blot was rinsed with four changes of $100 \mathrm{ml}$ of $10 \mathrm{mM}$ Tris- $\mathrm{HCl}, 154 \mathrm{mM} \mathrm{NaCl}$ (buffer C) and then incubated for $4 \mathrm{~h}$ with $20 \mathrm{ml}$ of buffer $\mathrm{B}$ containing ${ }^{125} \mathrm{I}$-protein $\mathrm{A}(20,000 \mathrm{cpm} / \mathrm{ml} ; 92.5 \mathrm{Ci} / \mathrm{mmol} ; \mathrm{New}$ England Nuclear, Boston, MA, U.S.A.) followed by washing with buffer $C$. Air-dried blots were subjected to autoradiography at $-70^{\circ} \mathrm{C}$ with $\mathrm{X}$-OMAT $\mathrm{x}$-ray film (Kodak, Rochester, NY, U.S.A.).

\section{In situ [ ${ }^{3}$ H]DOPA production}

In situ tyrosine hydroxylase activity was estimated by measuring the conversion of $\left[{ }^{3} \mathrm{H}\right]$ tyrosine to $\left[{ }^{3} \mathrm{H}\right] 3,4$-dihydroxyphenylalanine ( $\left.\left[{ }^{3} \mathrm{H}\right] \mathrm{DOPA}\right)$ according to a modification of Chalfie and Perlman (1977). Cells cultured in 16-mm diameter wells were incubated with $0.4 \mathrm{ml}$ of 150 $\mu M$ brocresine (an inhibitor of DOPA decarboxylase) in PSS for $30 \mathrm{~min}$ at $25^{\circ} \mathrm{C}$ and then replaced with $0.2 \mathrm{ml}$ of PSS containing $150 \mu M$ brocresine, 10 or $50 \mu M$ tyrosine, $10^{6} \mathrm{cpm}$ of $\left[{ }^{3} \mathrm{H}\right]$ tyrosine, and various drugs for indicated times. The reaction was terminated with $0.1 \mathrm{ml}$ of $1.2 \mathrm{M}$ perchloric acid. In some experiments $35-\mathrm{mm}$ diameter dishes were used with $0.8 \mathrm{ml}$ brocresine-containing PSS, $0.6 \mathrm{ml}\left[{ }^{3} \mathrm{H}\right]$ tyrosine-containing PSS, and $0.2 \mathrm{ml}$ perchloric acid. After perchloric acid addition the solution was added to $6 \mathrm{ml}$ of a solution ( $\mathrm{pH} \mathrm{8.6)}$ containing $1 M$ Tris, $0.04 M$ potassium phosphate, $1 \%$ EDTA, $15 \mathrm{mg} \mathrm{Na}_{2} \mathrm{~S}_{2} \mathrm{O}_{5}$, and $25 \mu \mathrm{l}$ of a solution containing $0.01 \mathrm{M} \mathrm{HCl}, 0.25 \mathrm{mg} /$ $\mathrm{ml}$ tyrosine, and $0.25 \mathrm{mg} / \mathrm{ml}$ 3,4-dihydroxyphenylethylamine (dopamine). The resulting solution was added to 0.8-cm diameter columns containing $200 \mathrm{mg}$ acid alumina. Columns were washed with $20 \mathrm{ml}$ distilled water prior to elution of $\left[{ }^{3} \mathrm{H}\right] D O P A$ with $3 \mathrm{ml}$ of $0.3 \mathrm{M} \mathrm{HCl}$. [ $\left.{ }^{3} \mathrm{H}\right] D O P A$ in aliquots were measured by scintillation counting and data expressed as pmol $\left[{ }^{3} \mathrm{H}\right] \mathrm{DOPA} / \mathrm{mg}$ protein.
Cyclic AMP measurement and protein measurements

Cells in 60-mm diameter dishes were incubated in $3 \mathrm{ml}$ PSS with various drugs. The solution was replaced with $0.6 \mathrm{ml} 5 \%$ trichloroacetic acid (TCA) to liberate cyclic AMP. The TCA was extracted three times with four volumes of ethyl ether and the aqueous extract was lyophilized. The cyclic AMP in the residue was assayed using a cyclic AMP assay kit (Amersham, Arlington Heights, IL, U.S.A.). Protein was measured by the method of Bradford (Bradford, 1976) using bovine serum albumin as a standard.

\section{Data and chemicals}

Data are expressed as means \pm SEM. Significance was tested by Student's $t$ test. Experiments were repeated two to five times. Carbachol, 1-1-dimethyl-4-phenylpiperazinium (DMPP), methacholine, atropine, muscarine, mecamylamine, acetylcholine, nicotine, dibutyryl cyclic AMP, tyrosine- $\mathrm{HCl}, 4 \beta$-phorbol $12 \beta$-myristate $13 \alpha$-acetate (TPA), HEPES, Tris-base, Triton X-100, Nonidet P40 , and bovine serum albumin were from Sigma ( $S t$. Louis, MO, U.S.A.). Dopamine, forskolin, and DL-6methyl-5,6,7,8-tetrahydropterine were from Calbiochem (San Diego, CA, U.S.A.). Brocresine was from Lederle Laboratory (Pearl River, NY, U.S.A.). Acrylamide was purchased from Kodak (Rochester, NY, U.S.A.).

\section{RESULTS}

\section{Cholinergic stimulation of tyrosine hydroxylase} phosphorylation in chromaffin cells

DMPP, a selective nicotinic agonist, stimulated phosphorylation of a 56-kilodalton protein in cells that had been preincubated with $\left.{ }^{{ }^{32}} \mathrm{P}\right]$ phosphate (Fig. 1). Mixed nicotinic-muscarinic agonists such as acetylcholine and carbachol stimulated comparable phosphorylation of the 56-kilodalton protein. Occasionally nicotinic stimulation resulted in phosphorylation of a 99-kilodalton protein; however, in many experiments, such as in Fig. 1, the phosphorylation was not detectable. The 56-kilodalton protein had a molecular weight similar to that of the subunits of purified tyrosine hydroxylase (Joh et al., 1978) and to a protein identified as tyrosine hydroxylase in suspended bovine chromaffin cells (Meligeni et al., 1982).

To determine whether the 56-kilodalton phosphoprotein was tyrosine hydroxylase, nonradiolabeled and $\left.{ }^{32} \mathrm{P}\right]$ phosphate-labeled proteins that had been separated by one-dimensional SDS-PAGE were electrophoretically transferred to nitrocellulose paper (Western blotting). Tyrosine hydroxylase in cells not incubated with [ $\left.{ }^{32} \mathrm{P}\right]$ phosphate was identified with anti-tyrosine hydroxylase antibody and ${ }^{125}$ I-protein A. Autoradiograms of the blots demonstrated that antibody to tyrosine hydroxylase labeled a protein that comigrated with the 56-kilodalton protein phosphorylated by the nicotinic agonist DMPP (Fig. 2). The DMPP-induced increase in ${ }^{32} \mathrm{P}$ incorporation into the 56 -kilodalton protein appears less in Fig. 2 than in Fig. 1 because of overexposure of ${ }^{32} \mathrm{P}$ bands in the autoradiogram of 


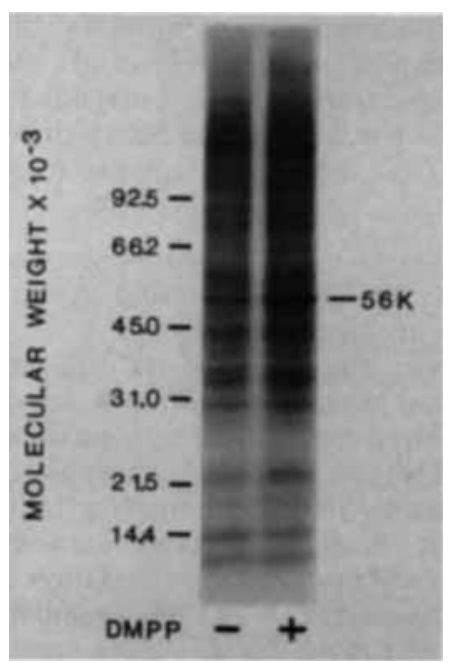

FIG. 1. Autoradiography of $\left[{ }^{32} \mathrm{P}\right]$ phosphate-containing proteins separated by one-dimensional SDS-PAGE. Chromaffin cells labeled with [ $\left.{ }^{32} \mathrm{P}\right]$ phosphate for $30 \mathrm{~min}$ were incubated for 5 min with PSS containing [ ${ }^{32}$ P]phosphate and with or without $10 \mu M$ DMPP. Phosphoproteins were analyzed by SDS-PAGE and autoradiography.

Fig. 2 and because of the somewhat qualitative nature of the protein transfer to the nitrocellulose paper.

Analysis of $\left[{ }^{32} \mathrm{P}\right]$ phosphoproteins by two-dimensional PAGE revealed that in unstimulated cells there were two phosphorylated proteins of 56 kilodaltons with pI values of approximately 6.36 and 6.27 (Fig. 3). Incubation of the cells with the nicotinic agonist DMPP increased the phosphorylation of these two proteins and in another protein at 56 kilodaltons, pI 6.15.

The possibility that the three phosphoproteins of 56 kilodaltons with pI values of approximately 6.37 , 6.27 , and 6.15 represent tyrosine hydroxylase was investigated by electrophoretically transferring the proteins from two-dimensional PAGE to nitrocellulose paper and subsequently using anti-tyrosine hydroxylase antibody. Two [ ${ }^{32}$ P]phosphoproteins of molecular weight of $56 \mathrm{~K}$ were observed in protein from control cells at $\mathrm{pI}$ values 6.37 and 6.25. The phosphorylation of these two proteins was increased by DMPP and another protein was also phosphorylated at pH 6.15 (Fig. $4 \mathrm{~A}$ and B). After 6 months, when the radioactivity had decayed to undetectable levels, the nitrocellulose papers were incubated with anti-tyrosine hydroxylase serum followed by ${ }^{125} \mathrm{I}$-protein $\mathrm{A}$. The resulting autoradiograms are shown (Fig. 4C and D). In the control (Fig. 4C) the anti-tyrosine hydroxylase antibody bound to three proteins of molecular weight of $56 \mathrm{~K}$ (pI values 6.5, 6.37, and 6.27). Blots of proteins from cells stimulated with nicotinic agonist had four proteins of molecular weight $56 \mathrm{~K}$ with pI values of

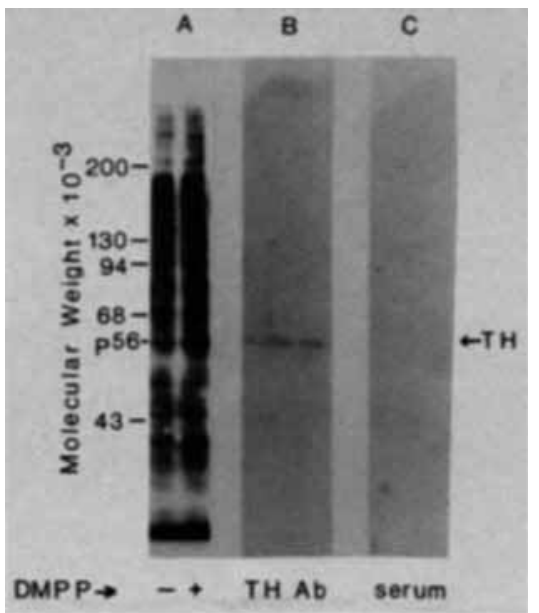

FIG. 2. Autoradiograms of Western blots from one-dimensional SDS-PAGE. A: Autoradiography of [ ${ }^{32}$ P]phosphoproteins. Cells labeled with [ $\left.{ }^{32} \mathrm{P}\right]$ phosphate were incubated in PSS with or without $10 \mu M$ DMPP for 5 min. Phosphoproteins were transferred from SDS-polyacrylamide slab gels to nitrocellulose paper. [ $\left.{ }^{32} \mathrm{P}\right]$ Phosphoproteins were visualized by autoradiography. B: Nonradioactive chromaffin cell proteins were transferred from SDS-polyacrylamide slab gels to nitrocellulose paper. Resulting blots were incubated with tyrosine hydroxylase antiserum and then with ${ }^{125}$-protein $A$ which was visualized by autoradiography. C: Same as (B) except that the blots were incubated with nonimmune serum followed by 125 -protein A. Incubation of blots with BSA-containing buffer (buffer A) prior to ${ }^{125}$ /-protein A did not result in protein visualization (data not shown).

$6.5,6.37,6.27$, and 6.15 which bound tyrosine hydroxylase antibody (Fig. 4D). These data confirm the identity of the $56 \mathrm{~K}$ phosphoprotein as tyrosine hydroxylase. In addition they identify four different forms of tyrosine hydroxylase subunit. One is not phosphorylated (pH 6.5) and three are phosphorylated but have different pI values $(6.37,6.27$, and 6.15).

The data provide strong evidence that the 56-kilodalton protein phosphorylated on nicotinic stimulation is tyrosine hydroxylase. The protein will be referred to as tyrosine hydroxylase in the rest of the paper.

DMPP sometimes caused phosphorylation of proteins in addition to tyrosine hydroxylase which were detected by two-dimensional PAGE; however, the phosphorylation of these proteins was not reproducible.

Cholinergic pharmacology of tyrosine hydroxylase phosphorylation, and catecholamine secretion

The selective nicotinic agonists nicotine and DMPP and the mixed nicotinic-muscarinic agonists carbachol and acetylcholine caused several-fold increases in the phosphorylation of tyrosine hydroxylase (Fig. 5A). The selective muscarinic agonists muscarine and methacholine caused only small increases in tyrosine hydroxylase phosphorylation. 


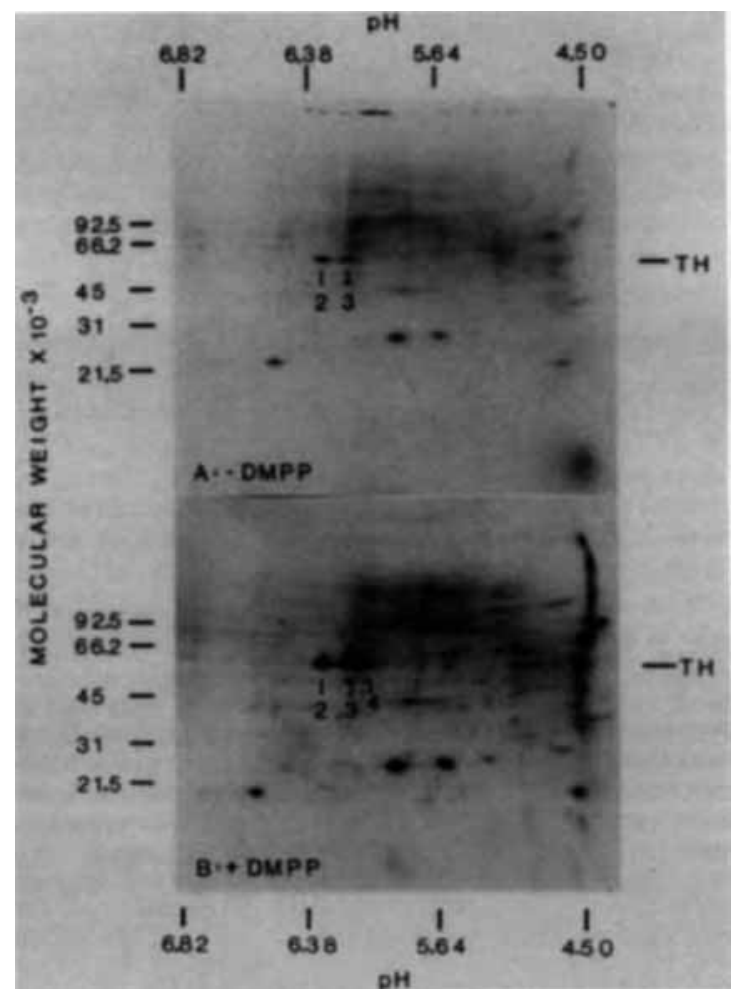

FIG. 3. Autoradiography of two-dimensional PAGE of [32P]phosphoprotein following nicotinic receptor stimulation. Chromaffin cells that had been labeled with [32P]phosphate for $30 \mathrm{~min}$ were incubated in PSS without (A) or with (B) $10 \mu M$ DMPP for 5 min. Phosphorylated cellular proteins were separated by two-dimensional PAGE (5-20\%) $(9 \mu \mathrm{g}$ protein/gel). The $\mathrm{pH}$ values attained are indicated along horizontal axis and the molecular weight markers are indicated on the left vertical axis. The extrapolated positions for p56 [ $\left.{ }^{32} \mathrm{P}\right]$ phosphoprotein are shown. The pl values of the multiple p56 phosphoproteins 2, 3, and 4 correspond to pl 6.37, 6.27 , and 6.15 , respectively.

Similarly the nicotinic antagonist mecamylamine was more potent in inhibiting carbachol-induced phosphorylation than the muscarinic antagonist atropine (Fig. 5B). Muscarinic agonists consistently caused a small but significant stimulation of tyrosine hydroxylase phosphorylation. In four out of four experiments methacholine or muscarine caused a 30-100\% enhancement of tyrosine hydroxylase phosphorylation (Fig. SA). The muscarinic agonist-induced phosphorylation was blocked by atropine ( $1 \mu M$; data not shown).

The data indicate that cholinergic stimulation of tyrosine hydroxylase phosphorylation occurred primarily through nicotinic receptor activation although there was a small stimulation of phosphorylation by activation of muscarinic receptors.

As reported previously catecholamine secretion was stimulated by agonists with nicotinic activity (nicotine, DMPP, carbachol, acetylcholine) but not by selective muscarinic agonists (muscarine, methacholine) (Fig. 5A) (Holz et al., 1982). Similarly the selective nicotinic antagonist mecamylamine had a much greater capacity than the selective muscarinic antagonist atropine to inhibit carbachol-induced secretion (Fig. 5B).

Time course of cholinergic stimulation of tyrosine hydroxylase phosphorylation and in situ

$\left[{ }^{3} \mathrm{H}\right]$ DOPA production

Cholinergic stimulation of tyrosine hydroxylase phosphorylation analyzed by one-dimensional SDSPAGE occurred rapidly and was maximal between 1 and 2 min (Fig. 6). The phosphorylation was about $70 \%$ maximal by $10 \mathrm{~s}$. The phosphorylation steadily declined but remained significant between 2 and 30 min. DMPP-stimulated phosphorylation of tyrosine hydroxylase analyzed by two-dimensional SDSPAGE demonstrated that the three subunits previously mentioned were significantly phosphorylated as early as $30 \mathrm{~s}$ and remained phosphorylated for at least 5 min (data not shown).

The time course of in situ $\left[{ }^{3} \mathrm{H}\right] \mathrm{DOPA}$ production by chromaffin cells was investigated as a measure of in situ tyrosine hydroxylase activity (Fig. 7). A reproducible increase in the rate of $\left[{ }^{3} \mathrm{H}\right] \mathrm{DOPA}$ production induced by DMPP could be detected by 2$5 \mathrm{~min}$. The rate decreased somewhat between 15 and $30 \mathrm{~min}$. The muscarinic agonist methacholine $(0.3 \mathrm{mM})$ did not significantly enhance $\left[{ }^{3} \mathrm{H}\right] \mathrm{DOPA}$ production (data not shown).

\section{Calcium dependency of tyrosine hydroxylase} phosphorylation and $\left[{ }^{3} \mathrm{H}\right] \mathrm{DOPA}$ production

Removal of calcium from the medium (medium contained $1 \mathrm{~m} M$ EGTA) reduced the phosphorylation of tyrosine hydroxylase in the absence of nicotinic agonist (Table 1) and completely inhibited subsequent carbachol-induced phosphorylation of tyrosine hydroxylase. Similar results were obtained with the selective nicotinic agonist DMPP (data not shown). In these experiments cells were first preincubated with $\mathrm{Ca}^{2+}$-free PSS with $1 \mathrm{~m} M$ EGTA to remove completely $\mathrm{Ca}^{2+}$. We found that without the preincubation in $\mathrm{Ca}^{2+}$-free medium, nicotinic stimulation in $\mathrm{Ca}^{2+}$-free PSS with $1 \mathrm{mM}$ EGTA resulted in transient phosphorylation that after $2 \mathrm{~min}$ was approximately $30 \%$ that attained by nicotinic stimulation in the presence of $\mathrm{Ca}^{2+}$.

Nicotinic agonist-induced increase in $\left.{ }^{3} \mathrm{H}\right] \mathrm{DOPA}$ production was also $\mathrm{Ca}^{2+}$-dependent (Table 2). Incubation of chromaffin cells in $\mathrm{Ca}^{2+}$-free PSS with $1 \mathrm{~m} M$ EGTA inhibited the DMPP-induced increase in $\left[{ }^{3} \mathrm{H}\right]$ DOPA production by $>90 \%$.

\section{Effects of noncholinergic secretagogues on} tyrosine hydroxylase phosphorylation and in situ [ ${ }^{3}$ H]DOPA production

Depolarization by elevated $\mathrm{K}^{+}$, which induces $\mathrm{Ca}^{2+}$-dependent catecholamine secretion from 


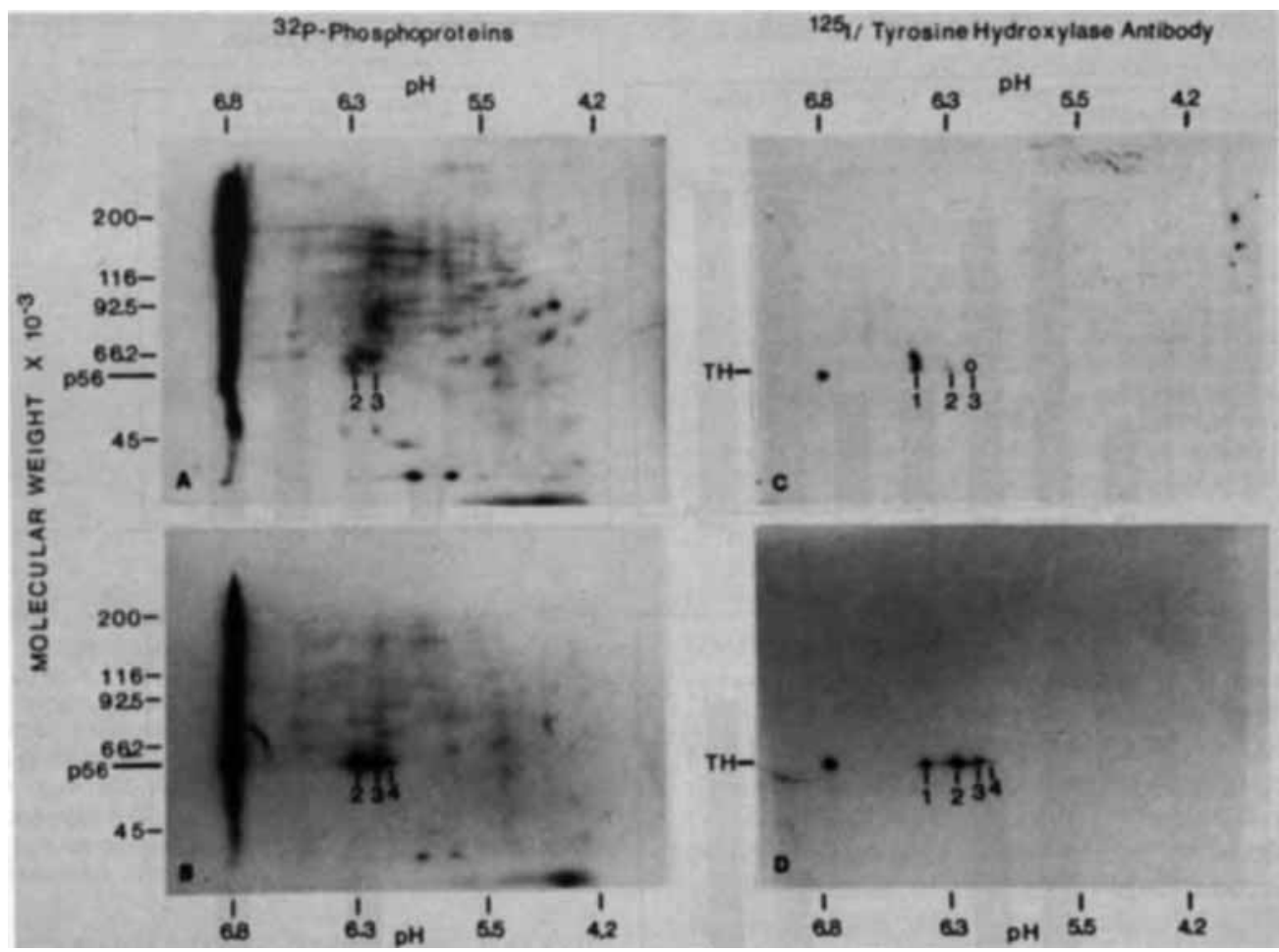

FIG. 4. Two-dimensional PAGE separation of phosphoprotein followed by Western blotting and immunochemical detection of tyrosine hydroxylase. Cellular [ $\left.{ }^{32} \mathrm{P}\right]$ phosphoproteins were separated by two-dimensional PAGE (6.9\%) after 5 -min incubation in PSS with or without $10 \mu M$ DMPP. Protein $(9 \mu \mathrm{g})$ was added to each gel. The [ ${ }^{32}$ P]phosphoproteins were electrophoretically transferred to nitrocellulose paper (Western blotting) and visualized by autoradiography either without DMPP (A) or with DMPP (B). The blots were stored at $4^{\circ} \mathrm{C}$ for 6 months to allow for ${ }^{32} \mathrm{P}$ decay. They were then analyzed for tyrosine hydroxylase using immunochemical detection (tyrosine hydroxylase antibody) and ${ }^{125}$-Protein $A$ according to methods (C) without DMPP or (D) with DMPP. Molecular weight markers are indicated on vertical ordinate and $\mathrm{pH}$ values attained by isoelectric focusing on the horizontal ordinates. The comigration of the p56 [ ${ }^{32}$ P]phosphoprotein and tyrosine hydroxylase (TH) visualized by ${ }^{125}$-Protein $A$ are indicated. Spots $1,2,3$, and 4 correspond to pl values $6.5,6.37,6.27$, and 6.15 , respectively. The circle on panel (C) represents spot 3 that is evident on the original autoradiogram.

chromaffin cells (Kilpatrick et al., 1982; Holz et al., 1982), also stimulated tyrosine hydroxylase phosphorylation (Fig. 8). Phosphorylation was maximal by $30 \mathrm{~s}$ when the rate of catecholamine secretion was maximal (Fig. 8). Elevated $\mathrm{K}^{+}$-induced phosphorylation was inhibited by $60 \%$ at $2 \mathrm{~min}$ and by $90 \%$ at $5 \mathrm{~min}$ in $\mathrm{Ca}^{2+}$-free medium (with $1 \mathrm{mM}$ EGTA) in cells that had not been preincubated in $\mathrm{Ca}^{2+}$-free medium. The phosphorylation was associated with a $\mathrm{Ca}^{2+}$-dependent increase in $\left.{ }^{3} \mathrm{H}\right]$ DOPA production (Table 3 ). $\mathrm{Ba}^{2+}$, which also stimulates catecholamine secretion, increased tyrosine hydroxylase phosphorylation (Fig. 9). The increased phosphorylation was also associated with an increase in $\left[{ }^{3} \mathrm{H}\right]$ DOPA production (Table 3 ).

To determine more precisely the pattern of tyrosine hydroxylase phosphorylation induced by elevated $\mathrm{K}^{+}$and $\mathrm{Ba}^{2+}$, two-dimensional polyacrylamide electrophoresis of the phosphorylated proteins was performed. ${ }^{32} \mathrm{P}$ incorporation increased in three forms of tyrosine hydroxylase at $\mathrm{pH}$ values of $6.37,6.27$, and 6.15 (Figs. 10 and 11 ). The pat- terns of phosphorylation induced by these secretagogues were very similar to that produced by nicotinic receptor stimulation.

\section{Cyclic AMP-induced increase in tyrosine hydroxylase phosphorylation and $\left[{ }^{3} \mathbf{H}\right]$ DOPA production}

Permeant analogues of cyclic AMP or forskolin, a potent activator of adenylate cyclase, cause little or no alteration of catecholamine secretion from bovine chromaffin cells (data not shown). However, cyclic AMP-dependent protein kinase phosphorylates and activates tyrosine hydroxylase in vitro (Joh et al., 1978; Yamauchi and Fujisawa, 1979) and cyclic AMP analogues and forskolin phosphorylate and activate tyrosine hydroxylase in bovine chromaffin cells (Meligeni et al., 1982). We also found that forskolin increased the phosphorylation of tyrosine hydroxylase in chromaffin cells (Fig. 12). Tyrosine hydroxylase subunits with $\mathrm{pl}$ values of 6.37 and 6.27 were relatively strongly phosphorylated 
A. Agonists
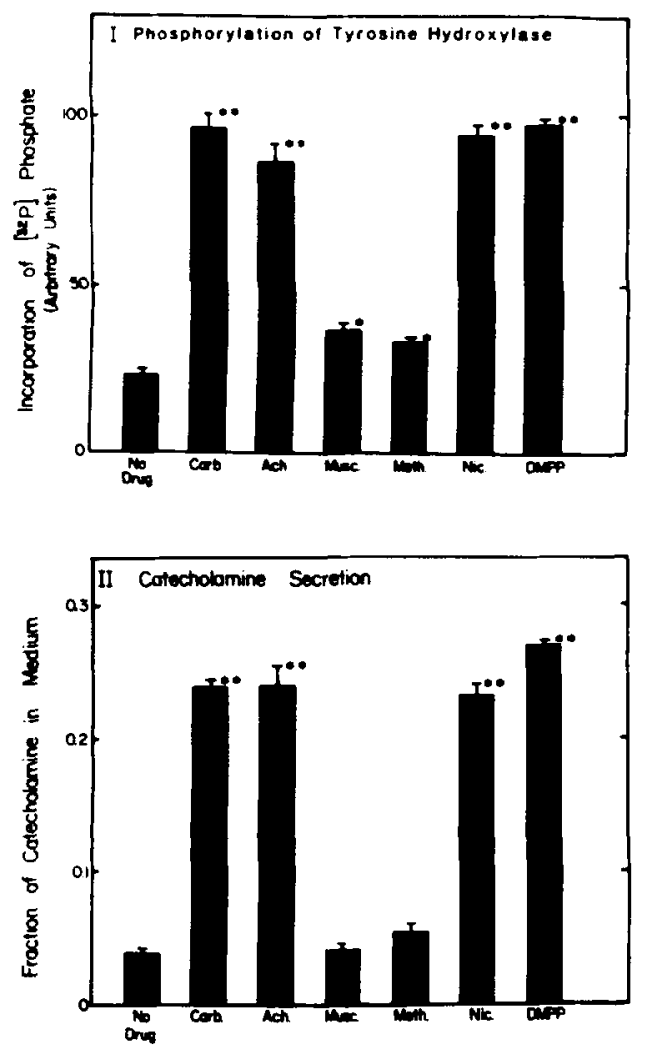

B. Antogonists
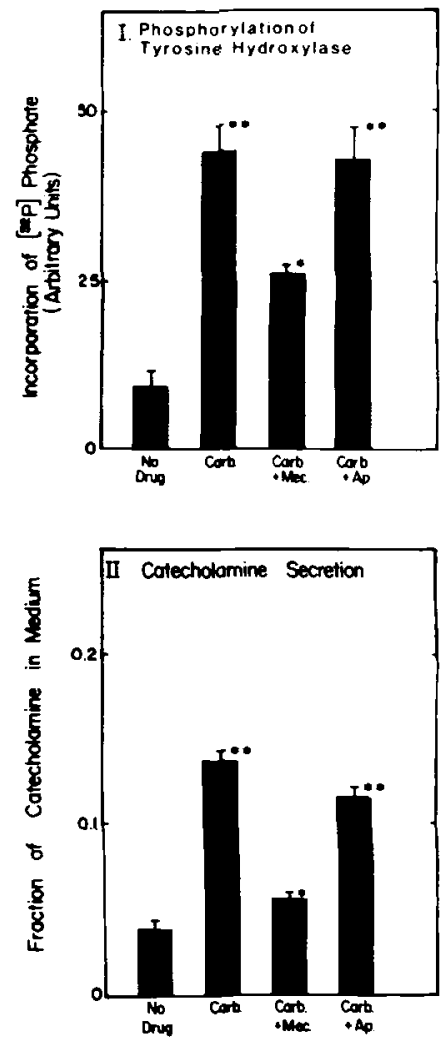

F1C. 5. The effects of various agonists (A) and antagonists (B) on tyrosine hydroxylase phosphorylation and on catecholamine secretion. Protein phosphorylation was determined after 5 min in test solutions. The amount of catecholamine secretion was measured atter 15 min in test solution. In (A), test solutions contained: no drug, no addition; Carb., carbachol $3 \times 10^{-4} M$; Ach., acetylcholine $3 \times 10^{-4} \mathrm{M}$; Musc., muscarine $3 \times 10^{-4} \mathrm{M}$; Meth., methacholine $3 \times 10^{-4} M$; Nic., nicotine $10 \mu M$; DMPP, 10 $\mu M$. In (B), test solutions contained: Mec., mecamylamine $6 \mu M$ or Ap., atropine $6 \mu M$, and Carb., carbachol $3 \times 10^{-4} M$.

and the subunit of 6.15 was relatively weakly phosphorylated. Dibutyryl cyclic AMP $(1 \mathrm{mM})$ also caused phosphorylation of tyrosine hydroxylase subunits but to a smaller degree than forskolin (10 $\mu M$ ) (data not shown). [ ${ }^{3} \mathrm{H}$ ]DOPA production was increased by forskolin and to a lesser degree by dibutyryl cyclic AMP (Table 4).

\section{Nicotinic-agonist-induced elevation of chromaffin cell cyclic AMP}

Because elevation of cyclic AMP during cholinergic stimulation of chromaffin cells could have resulted in tyrosine hydroxylase phosphorylation and activation, the effect of carbachol on the level of cyclic AMP in chromaffin cells was investigated. Carbachol caused a two- to threefold increase in cyclic AMP between 2 and $5 \mathrm{~min}$, which decreased by 15 min (Fig. 13). DMPP caused a similar time course of cyclic AMP accumulation (data not shown). The carbachol-induced rise of cyclic AMP was dependent on medium $\mathrm{Ca}^{2+}$ (Table 5).
It is possible that the rise in cyclic AMP resulted not directly from cholinergic receptor stimulation, but instead from stimulation of chromaffin cell adenylate cyclase by agents secreted from the chromaffin cells. This possibility is unlikely since the medium collected from the cell culture which had been subjected to an increased secretion by DMPP failed to stimulate cyclic AMP production in other cell cultures in the presence of $1 \mu M$ mecamylamine (to inhibit direct nicotinic stimulation) (data not shown).

\section{DISCUSSION}

Cholinergic stimulation of multiple phosphorylated forms of tyrosine hydroxylase

Previous studies with monolayer cultures of bovine chromaffin cells demonstrated that a 56-60kilodalton protein was phosphorylated when cells were stimulated to secrete with acetylcholine or other secretagogues (Holz et al., 1980; Amy and Kirshner, 1981). A protein with subunits of similar 


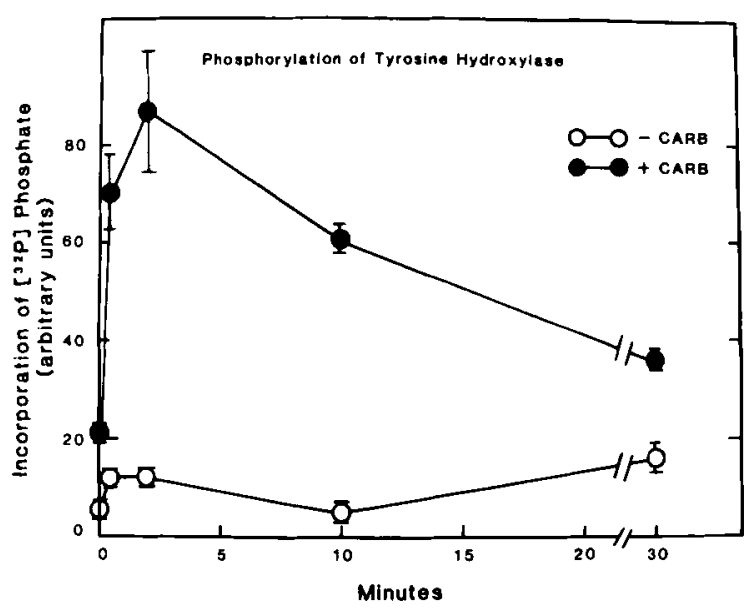

FiG. 6. Time course of carbachol-stimulated tyrosine hydroxylase phosphorylation. Cells which had been preincubated for $30 \mathrm{~min}$ in [ ${ }^{32} \mathrm{P}$ ]phosphate containing solution were incubated in nonradioactive PSS solution with or without 0.3 $\mathrm{mM}$ carbachol for the indicated times and analyzed for phosphoproteins on one-dimensional PAGE. The zero time points represent data from cells transiently incubated with or without carbachol. There were three wells/group. A similar time course was obtained when [32P]phosphate was present during incubation with agonist.

molecular weight, tyrosine hydroxylase, was demonstrated by immunoprecipitation to be phosphorylated on incubation of suspended chromaffin cells with acetylcholine (Haycock et al., 1982a). The phosphorylation was associated with an increase in in situ DOPA production, which suggested that the phosphorylation activated tyrosine hydroxylase. In the present study with monolayer cultures of bovine adrenal chromaffin cells we determined using immunodetection on Western blots from both one- and two-dimensional polyacrylamide gels that the phos-

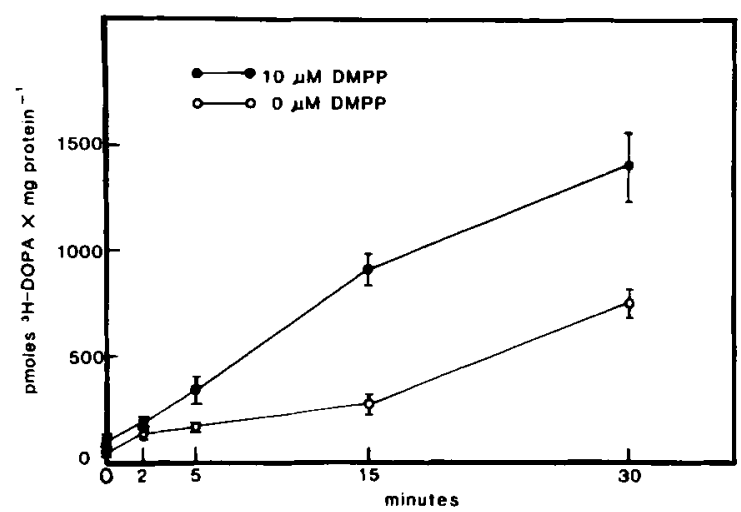

FIG. 7. Time course of nicotinic stimulation of in situ $\left[{ }^{3} \mathrm{H}\right]$ DOPA production. $\left[{ }^{3} \mathrm{H}\right]$ DOPA production from $\left[{ }^{3} \mathrm{H}\right]$ tyrosine was measured following incubation of cells in PSS with or without $10 \mu M$ DMPP for various times. There were four wells/group. DMPP caused a statistically significant increase $(p<0.05-0.001)$ in $\left[{ }^{3} \mathrm{H}\right]$ DOPA production at 5,15 , and 30 min.
TABLE 1. $\mathrm{Ca}^{2+}$ dependency of carbachol-induced tyrosine hydroxylase phosphorylation

\begin{tabular}{llc}
\hline Calcium & Carbachol & $\begin{array}{c}\left.{ }^{32} \mathrm{P}\right] \text { Phosphate incorporation } \\
\text { (Arbitrary units) }\end{array}$ \\
\hline 0 & 0 & $11.8 \pm 1.1$ \\
0 & $0.3 \mathrm{mM}$ & $13.0 \pm 1.5$ \\
$2.2 \mathrm{mM}$ & 0 & $25.0 \pm 1.1^{a}$ \\
$2.2 \mathrm{mM}$ & $0.3 \mathrm{mM}$ & $71.2 \pm 1.2^{a, b}$ \\
\hline
\end{tabular}

Cells that were labeled with PSS containing [ ${ }^{32}$ Plphosphate for $30 \mathrm{~min}$ were further incubated for $10 \mathrm{~min}$ with PSS containing [32. P]phosphate and either 0 calcium and $1 \mathrm{mM}$ EGTA or $2.2 \mathrm{mM}$ calcium and no EGTA. Protein phosphorylation was measured after a subsequent 30-s incubation in PSS containing 0 or 2.2 $\mathrm{mMC \textrm {Ca } ^ { 2 + }}$ in the presence or absence of $0.3 \mathrm{mM}$ carbachol. There were four wells/group.

${ }^{a} \mathrm{p}<0.001$ versus $0 \mathrm{Ca}^{2+} / 0$ carbachol.

${ }^{b} \mathrm{p}<0.001$ versus $\mathrm{Ca}^{2+} / 0$ carbachol.

phorylated 56-kilodalton protein which we had observed was tyrosine hydroxylase. The antibody used was different from the one used by Meligni et al. (1982). In one-dimensional analysis the 56-kilodalton protein comigrated with a protein that bound tyrosine hydroxylase antibody. In two-dimensional PAGE analysis of unstimulated cells there were small amounts of phosphorylated proteins at molecular weight $56 \mathrm{~K}$ with $\mathrm{pI}$ values of 6.37 and 6.27 which were subunits of tyrosine hydroxylase. Cholinergic stimulation of chromaffin cells caused the phosphorylation of three proteins at molecular weight of $56 \mathrm{~K}$ at pI values of approximately 6.37 , 6.27 , and 6.15 which were tyrosine hydroxylase subunits. The immunochemical analysis also revealed that there was unphosphorylated tyrosine hydroxylase with a molecular weight of $56 \mathrm{~K}$ and a pI of 6.5. Although the transfer of proteins to nitrocellulose paper in Western blots is only semiquantitative, the data suggest that on cholinergic stimulation there was a decrease in the unphosphorylated form and an increase in the phosphorylated forms of tyrosine hydroxylase. Thus, a substantial fraction of the tyrosine hydroxylase was probably phosphorylated on nicotinic stimulation. The shift to more acidic subunits on phosphorylation is a pos-

TABLE 2. $C \mathrm{a}^{2+}$ dependency of nicotinic agonist-induced $\left[^{3}\right.$ H]DOPA production

\begin{tabular}{lcc}
\hline Calcium & DMPP & pmol $\left[{ }^{3} \mathrm{H}\right]$ DOPA $/ 5 \mathrm{~min} / \mathrm{mg}$ protein \\
\hline 0 & 0 & $117.3 \pm 22.3$ \\
0 & $10 \mu M$ & $139.4 \pm 24.0$ \\
$2.2 \mathrm{mM}$ & 0 & $140.2 \pm 15.6$ \\
$2.2 \mathrm{mM}$ & $10 \mu M$ & $422.8 \pm 28.0^{\circ}$ \\
\hline
\end{tabular}

Cells were incubated for $10 \mathrm{~min}$ with $\mathrm{Ca}^{2+}$-containing PSS or $\mathrm{Ca}^{2+}$-free PSS with $1 \mathrm{mM}$ EGTA and the incubation medium changed to the same buffer with and without DMPP and containing $50 \mu M\left[{ }^{3} \mathrm{H}\right]$ tyrosine $\left(1 \times 10^{7} \mathrm{cpm} / \mathrm{ml}\right)$. $\left.{ }^{3} \mathrm{H}\right] \mathrm{DOPA}$ production was assayed after $15 \mathrm{~min}$. There were four wells/group and $50 \mu \mathrm{g}$ protein/well.

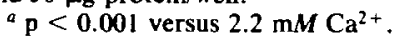


sible effect of phosphorylation (Garrison and Wagner, 1982).

\section{Cholinergic pharmacology of tyrosine hydroxylase phosphorylation}

The effects of nicotinic and muscarinic agonists and antagonists indicate that the three- to fourfold increase in tyrosine hydroxylase phosphorylation induced by the mixed nicotinic-muscarinic agonists acetylcholine or carbachol was caused predominantly by stimulation of nicotinic receptors. Associated with the nicotinic receptor mediated increase in phosphorylation was an increase in $\left[{ }^{3} \mathrm{H}\right] \mathrm{DOPA}$ production which probably reflects an increase of in situ tyrosine hydroxylase activity. Muscarinic agonists reproducibly caused a small (less than two-
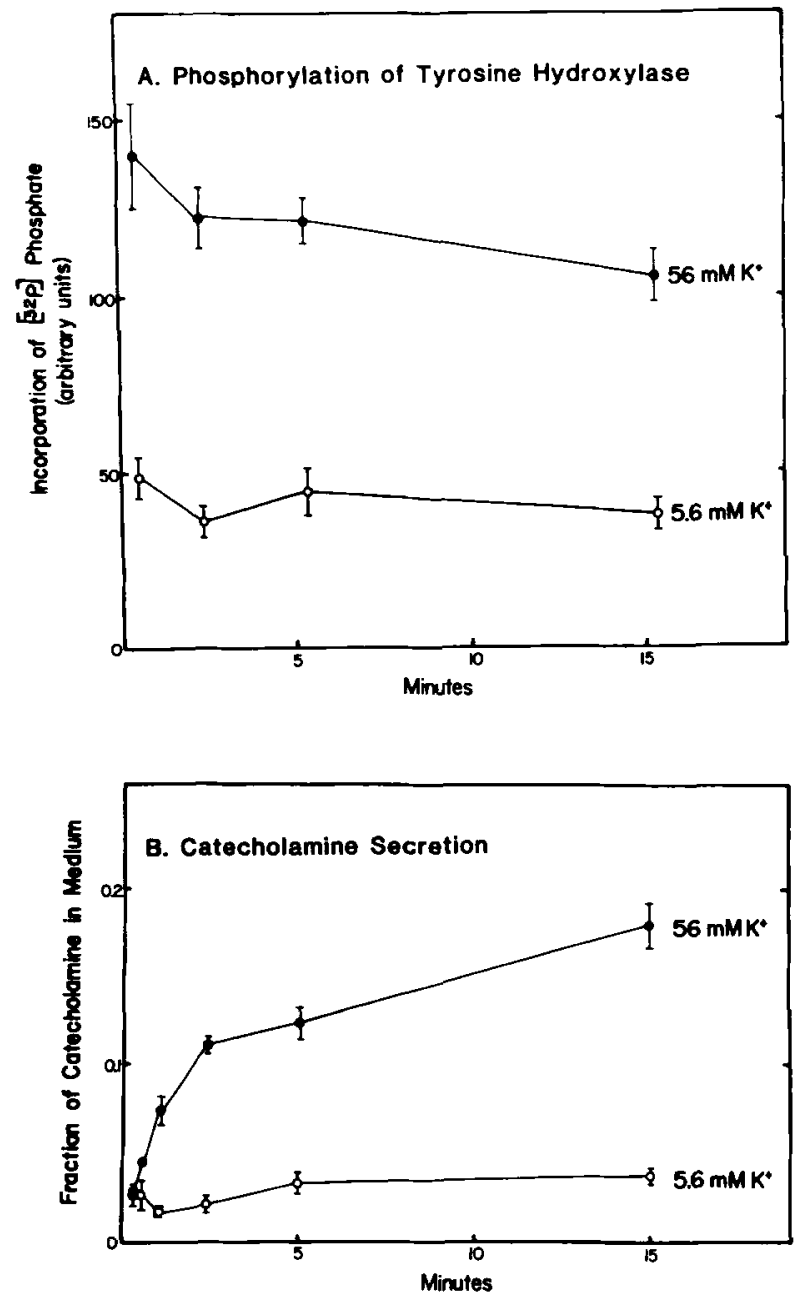

FIG. 8. Time course of tyrosine hydroxylase phosphorylation (A) and catecholamine secretion (B) induced by elevated potassium. Tyrosine hydroxylase phosphorylation and catecholamine secretion were assayed following incubation of chromaffin cells for the indicated times in PSS with $5.6 \mathrm{mM}$ or $56 \mathrm{mM} \mathrm{KCl}$ in the continued presence of [ $\left.{ }^{32} \mathrm{P}\right]$ phosphate. There were three wells/group.
TABLE 3. Effects of $\mathrm{Ba}^{2+}$ and elevated $\mathrm{K}^{+}$on in situ $l^{3}$ H]DOPA production

\begin{tabular}{lc}
\multicolumn{1}{c}{ Group } & pmol $\left[{ }^{3} \mathrm{H}\right] \mathrm{DOPA} / 15 \mathrm{~min} / \mathrm{mg}$ protein \\
\hline Experiment 1 & \\
$\mathrm{Ca}^{2+}$ & $84.3 \pm 15.8$ \\
$\mathrm{Ca}^{2+} / 56 \mathrm{mM} \mathrm{KCl}$ & $221.4 \pm 17.6^{a}$ \\
$0 \mathrm{Ca} \mathrm{a}^{2+} / \mathrm{EGTA}$ & $70.8 \pm 4.5$ \\
$0 \mathrm{Ca} / \mathrm{EGTA} / 56 \mathrm{mM} \mathrm{KCl}$ & $75.2 \pm 10.0$ \\
Experiment 2 & $29.9 \pm 2.3$ \\
$2.2 \mathrm{mM} \mathrm{CaCl}_{2}$ & $73.1 \pm 4.3^{b}$ \\
$2.2 \mathrm{mM} \mathrm{BaCl}_{2}$ & \\
\hline
\end{tabular}

In experiment 1 cells were incubated for $15 \mathrm{~min}$ in either PSS with $2.2 \mathrm{mM} \mathrm{Ca}^{2+}$ or $\mathrm{Ca}^{2+}$-free PSS with $1 \mathrm{mM}$ EGTA and then further incubated for $15 \mathrm{~min}$ in the continuing presence or absence of $\mathrm{Ca}^{2+}$ or EGTA solution containing $\left[{ }^{3} \mathrm{H}\right]$ tyrosine $(10 \mu M)$ with either $5.6 \mathrm{mM} \mathrm{KCl}$ or $56 \mathrm{mM} \mathrm{KCl}$. In experiment 2 cells were incubated with $\left[{ }^{3} \mathrm{H}\right]$ tyrosine $(10 \mu M)$ for $15 \mathrm{~min}$ in PSS or in $\mathrm{Ca}^{2+}$-free PSS with $2.2 \mathrm{mM} \mathrm{BaCl}{ }_{2}$. There were five samples/ group in both experiments. Experiments 1 and 2 were performed on different cell preparations.

${ }^{a} \mathrm{p}<0.001$ versus $\mathrm{Ca}^{2+}$.

${ }_{b} \mathrm{p}<0.001$ versus $\mathrm{Ca}^{2+}$.

fold) increase in tyrosine hydroxylase phosphorylation that could be blocked by the muscarinic antagonist atropine. Therefore, it is likely that muscarinic receptor stimulation can cause a small but significant increase in tyrosine hydroxylase phosphorylation. An increase in [ $\left.{ }^{3} \mathrm{H}\right]$ DOPA production could not be detected on muscarinic stimulation, perhaps because of limited sensitivity of the assay employed to monitor in vitro tyrosine hydroxylase activity.

Relationship of tyrosine hydroxylase phosphorylation and other events in chromaffin cells stimulated with secretagogues

Nicotinic agonists and elevated $\mathrm{K}^{+}$cause detectable ${ }^{45} \mathrm{Ca}^{2+}$ entry into chromaffin cells by $15 \mathrm{~s}$ (Kilpatrick et al., 1982; Holz et al., 1982) which often precedes detectable catecholamine secretion. The rapid ${ }^{45} \mathrm{Ca}^{2+}$ entry initiated by nicotinic stimulation coincides with the rapid phosphorylation of tyrosine hydroxylase and precedes by $2 \mathrm{~min}$ a significant increase in cyclic AMP. Forskolin, which causes a larger increase in intracellular cyclic AMP (a sixfold increase; data not shown) than secretagogues, caused a smaller degree of tyrosine hydroxylase phosphorylation. Thus, the initial $\mathrm{Ca}^{2+}$. dependent phosphorylation of tyrosine hydroxylase is probably not mediated by a rise in cyclic AMP. $\mathrm{Ba}^{2+}$ alone stimulates exocytosis in the absence of medium $\mathrm{Ca}^{2+}$, probably by entering the cells and either releasing stored $\mathrm{Ca}^{2+}$ or mimicking the effects of $\mathrm{Ca}^{2+} \cdot \mathrm{Ba}^{2+}$ also stimulated tyrosine hydroxylase phosphorylation and $\left[{ }^{3} \mathrm{H}\right] \mathrm{DOPA}$ production. Nicotinic agonists and elevated $\mathrm{K}^{+}$and $\mathrm{Ba}^{2+}$, all caused rapid phosphorylation of the same three subunits of tyrosine hydroxylase. The data are consistent with the notion that these secretagogues lead to the activation of a common, $\mathrm{Ca}^{2+}$-dependent 

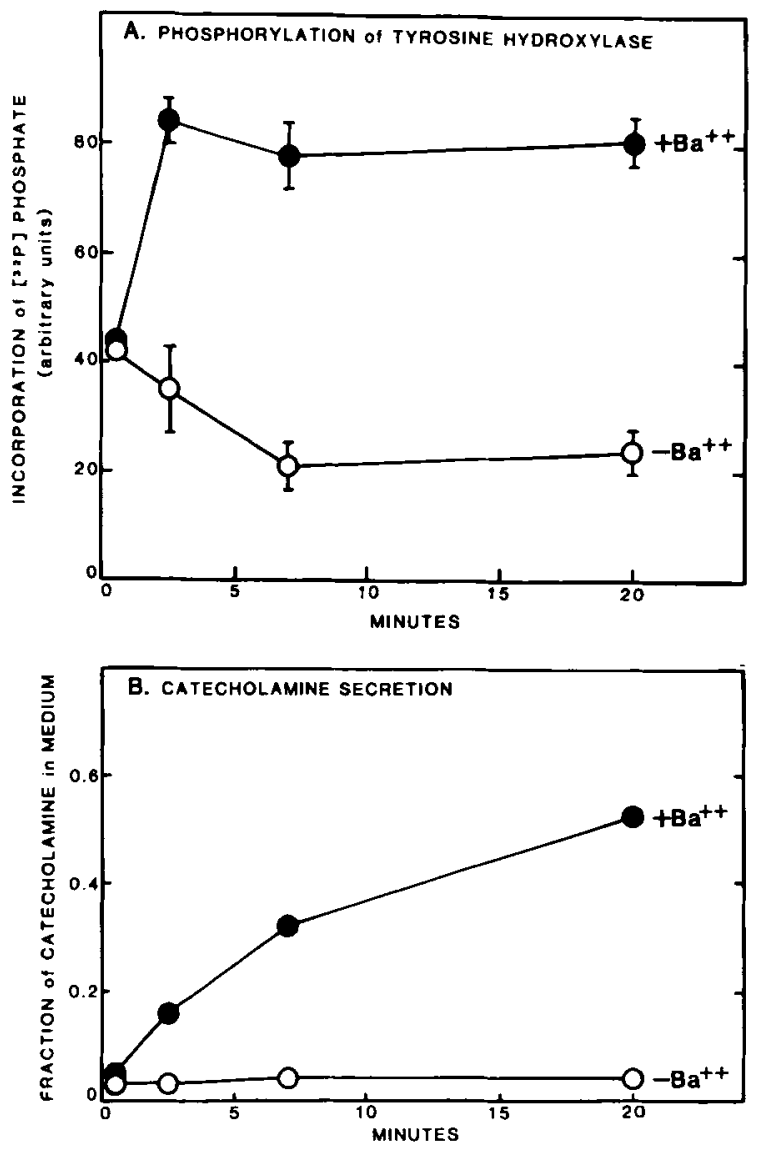

FIG. 9. Time course of $\mathrm{Ba}^{2+}$-induced tyrosine hydroxylase phosphorylation (A) and catecholamine secretion (B). A: Chromaffin cells labeled with [32P]phosphate were incubated in $\mathrm{Ca}^{2+}$-free PSS containing [ $\left.{ }^{32} \mathrm{P}\right]$ phosphate with or without $2.2 \mathrm{mM} \mathrm{Ba}^{2+}$. At the indicated times protein phosphorylation was determined. B: Same experiment as in (A) except that [ ${ }^{32}$ P]phosphate was absent. At the indicated times catecholamine secretion was determined. There were three wells/ group.

protein kinase, which catalyzes the phosphorylation of tyrosine hydroxylase and thereby enhances enzyme activity.

Recent evidence suggests that the rise in cyclic AMP induced by secretagogues results not from a direct stimulation of adenylate cyclase but by $\mathrm{Ca}^{2+}$ dependent stimulation of adenylate cyclase caused by the rise in intracellular $\mathrm{Ca}^{2+}(\mathrm{S}$. L. Pocotte, R. W. Holz, and M. E. Gnegy, unpublished observations).

The rates of ${ }^{45} \mathrm{Ca}^{2+}$ influx and catecholamine secretion are maximal during the first 2 min and then decrease to minimal levels by $15 \mathrm{~min}$ (Holz et al., 1982). The level of tyrosine hydroxylase phosphorylation is maximal by $1 \mathrm{~min}$ and falls to only onehalf its maximal value by $15 \mathrm{~min}$. The elevated state of phosphorylation of tyrosine hydroxylase at 15 min may result from subsequent activation of a protein kinase, perhaps by cyclic AMP, or may result from a relative lack of dephosphorylation.

Tyrosine hydroxylase is a substrate for $\mathrm{Ca}^{2+}$, calmodulin-dependent protein kinase (Yamauchi et al., 1981; Vulliet et al., 1984). If this protein kinase is responsible for the activation of tyrosine hydroxylase, then the cultured chromaffin cells probably contain an activator protein that is required for enhanced enzyme activity (Yamauchi et al., 1981). Tyrosine hydroxylase is also a substrate for the $\mathrm{Ca}^{2+}$, phospholipid-dependent protein kinase, protein kinase $C$ (Albert et al., 1984). We have recently found that phorbol esters that activate protein kinase $\mathrm{C}$ within cells cause phosphorylation of tyrosine hydroxylase (Pocotte et al., 1985) and stimulate $\left[{ }^{3} \mathrm{H}\right]$ DOPA production (Pocotte and Holz, 1986). The subunit phosphorylation induced by phorbol ester is identical to that caused by nicotinic stimulation. However, we have no evidence that protein

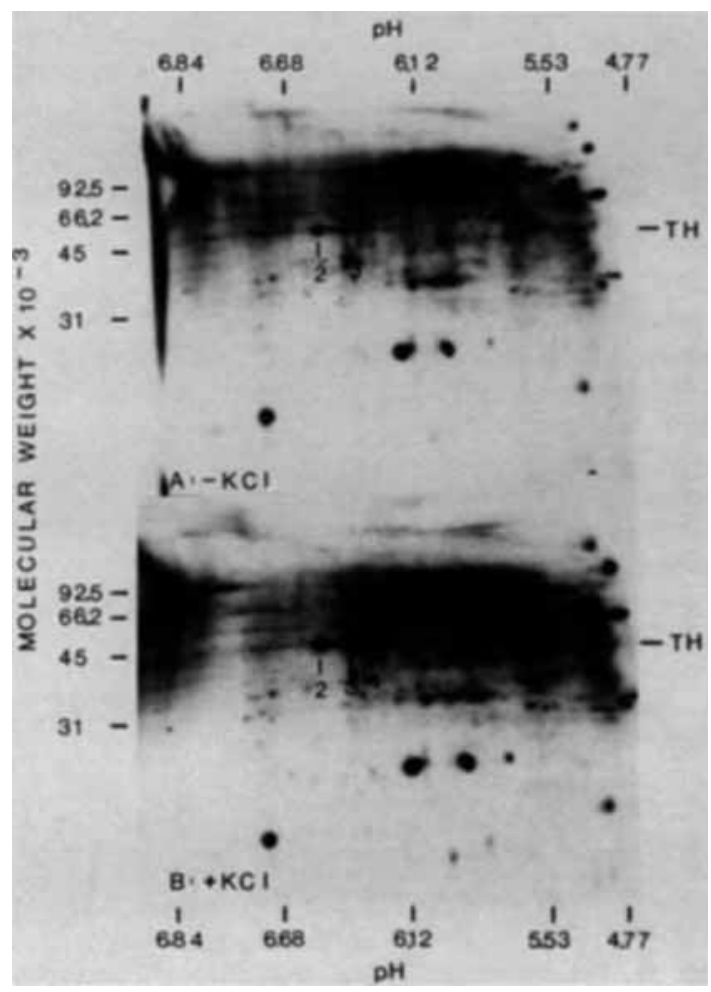

FIG. 10. Two-dimensional PAGE analysis of $\left[{ }^{32} \mathrm{P}\right]$ phosphoproteins following stimulation with $56.0 \mathrm{mM} \mathrm{KCl}$. Cells that had been labeled with [32P]phosphate were incubated with $2.2 \mathrm{mM}$ calcium PSS with $5.6 \mathrm{mM} \mathrm{KCl}$ (A) or $56.0 \mathrm{mM} \mathrm{KCl}$ (B) for $15 \mathrm{~min}$. Resulting [32P]phosphoproteins were separated by two-dimensional PAGE (5-20\%) (9 $\mu \mathrm{g}$ protein per gel). The $\mathrm{pH}$ values attained by isoelectric focusing are indicated on horizontal axis while the molecular weight markers are indicated on left vertical axis. Tyrosine hydroxylase (TH) is designated on right vertical axis. Spots 2,3 , and 4 correspond to pl values $6.37,6.27$, and 6.15 , respectively. 
kinase $C$ is activated by nicotinic stimulation. $1 t$ is possible that the small degree of phosphorylation stimulated by muscarinic stimulation results from activation of protein kinase $\mathrm{C}$ induced by muscarinic stimulation of the phosphatidylinositol cycle and the production of diacylglycerol (Fisher et al., 1981; Nishizuka, 1984). Muscarinic stimulation of the superior cervical ganglion of the rat results in tyrosine hydroxylase activation and stimulation of phosphatidylinositol metabolism (Horwitz et al., 1984).

Although the nicotinic receptor-stimulated phosphorylation of tyrosine hydroxylase was significant by $10 \mathrm{~s}$, the increased $\left[{ }^{3} \mathrm{H}\right] D O P A$ production was not significant until between 2 and $5 \mathrm{~min}$. The lag may reflect the time necessary for $\left[{ }^{3} \mathrm{H}\right]$ tyrosine to be taken up by the cells, other technical limitations of the assay, or the time necessary for activation of tyrosine hydroxylase after phosphorylation. Rapid phosphorylation but slower activation of tyrosine

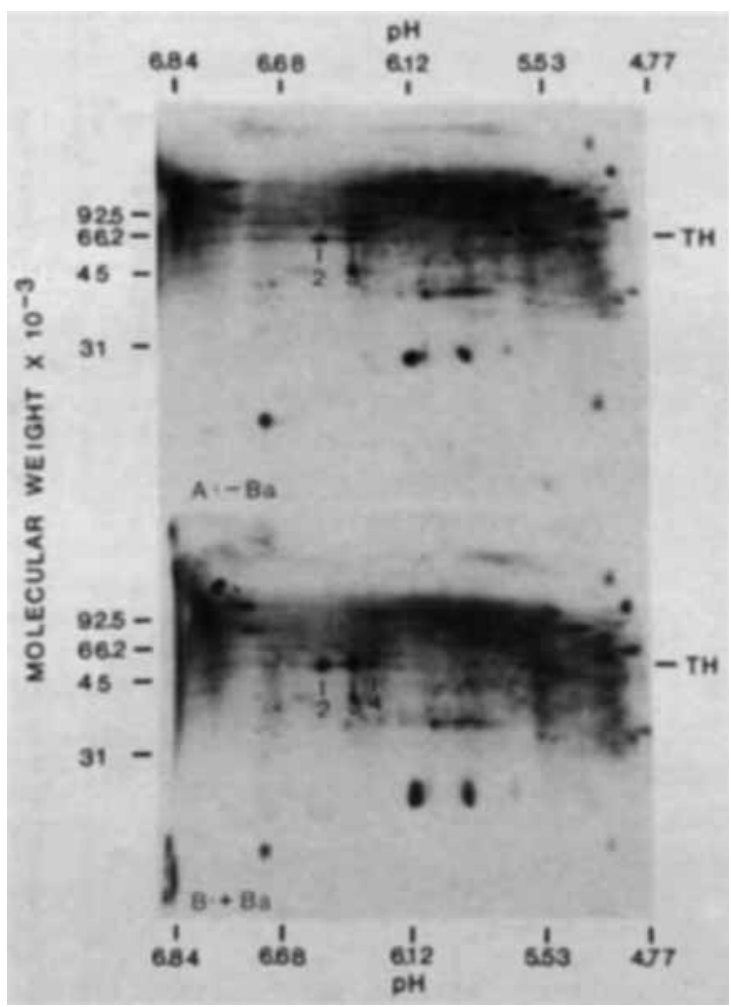

FIG. 11. Two-dimensional PAGE analysis of [ $\left.{ }^{32} \mathrm{P}\right]$ phosphoproteins following barium stimulation. Cells that had been labeled with [ $\left.{ }^{32} \mathrm{P}\right]$ phosphate were incubated with 0 calcium PSS (without EGTA) for 1 min. [32Plphosphoproteins were separated by two-dimensional PAGE ( $9 \mu \mathrm{g}$ protein per gel) following a 15 minute incubation in 0 calcium PSS (without EGTA) (A) or 0 calcium PSS with $2.2 \mathrm{mM} \mathrm{BaCl}$ (B). The pH values attained by isoelectric focusing are indicated along horizontal axis and the molecular weight markers are indicated on the left vertical axis. Tyrosine hydroxylase (TH) is designated on right vertical axis. Spots 2,3 , and 4 correspond to $\mathrm{pl}$ values $6.37,6.27$, and 6.15 , respectively.

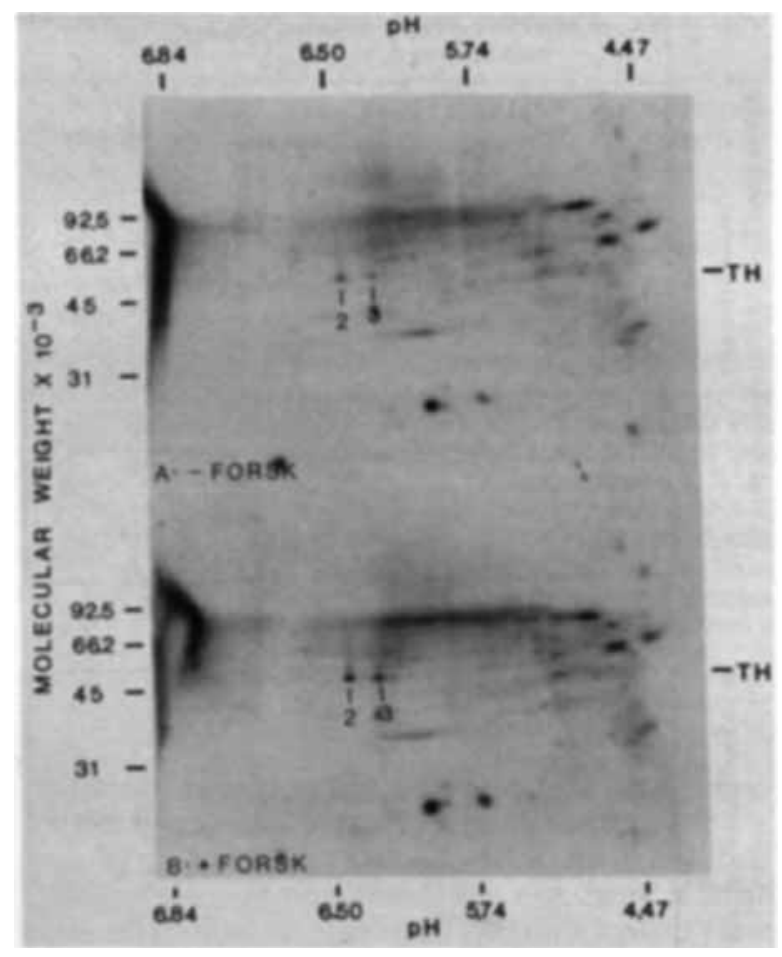

FIG. 12. Two-dimensional PAGE analysis of $\left[{ }^{32} \mathrm{P}\right]$ phosphoproteins following stimulation by forskolin. Cells that had been labeled with [ ${ }^{32}$ P]phosphate were incubated in PSS without (A) or with (B) $10 \mu \mathrm{M}$ forskolin for $30 \mathrm{~min}$. [32P]Phosphoproteins were separated by two-dimensional PAGE $(5-20 \%)(9 \mu \mathrm{g}$ protein per gel). The $\mathrm{pH}$ values attained by isoelectric focusing are indicated on the horizontal axis and the molecular weight markers along the left vertical axis. Tyrosine hydroxylase $(\mathrm{TH})$ is designated on right vertical axis. Spots 2 and 3 correspond to $p \mid$ values 6.37 and 6.27 , respectively.

hydroxylase was also observed in PC12 cells (Yanagihara et al., 1984).

In summary, the phosphorylation and activation of tyrosine hydroxylase, the rate-limiting step in catecholamine biosynthesis, occurs coincidentally with catecholamine secretion and is probably triggered by the rise in cytosolic $\mathrm{Ca}^{2+}$ which triggers exocytosis. Although the phosphorylation of tyrosine hydroxylase is unlikely to play a direct role in

TABLE 4. Effects of DBcAMP and forskolin on in situ $\left.I^{3} H\right] D O P A$ production

\begin{tabular}{cc}
\hline Group & pmol $\left[{ }^{3} \mathrm{H}\right] \mathrm{DOPA} / 30 \mathrm{~min} / \mathrm{mg}$ protein \\
\hline No additions & $23.7 \pm 1.0$ \\
$5 \mathrm{mM}$ DBcAMP & $43.6 \pm 2.0^{a}$ \\
$10 \mu M$ forskolin & $121.0 \pm 7.0^{b}$ \\
\hline
\end{tabular}

Cells were incubated in PSS containing $\left[{ }^{3} \mathrm{H}\right]$ tyrosine $(10 \mu M)$ with or without $5 \mathrm{~m} M$ DBcAMP or $10 \mu M$ forskolin. [ $\left.{ }^{3} \mathrm{H}\right] \mathrm{DOPA}$ production was assayed after $30 \mathrm{~min}$. There were four samples/ group.

${ }^{a} \mathrm{p}<0.01$ versus no additions.

${ }^{b} \mathrm{p}<0.001$ versus no additions. 
exocytosis, its regulation in the chromaffin cell represents a short-term response of the cell to replenish its catecholamine stores.

\section{Relationship to other studies of phosphorylation} in bovine chromaffin cells

Amy and Kirshner (1981) described a 60-kilodalton protein that was phosphorylated by a variety of secretagogues including nicotinic agonists, elevated $\mathrm{K}^{+}$and $\mathrm{Ba}^{2+}$. Because of the similar stimulation of phosphorylation of tyrosine hydroxylase in the present study, it is likely that the protein observed by Amy and Kirshner was tyrosine hydroxylase.

Waymire and colleagues (Meligeni et al., 1982; Haycock et al., 1982a,b) demonstrated that both acetylcholine and cyclic AMP mediated tyrosine hydroxylase phosphorylation and activation in suspended bovine chromaffin cells. They did not examine the pharmacology of the cholinergic effect nor the effects of $\mathrm{Ba}^{2+}$. They demonstrated using two-dimensional gels of tryptic fragments of cellular tyrosine hydroxylase that there were different phosphorylation sites that resulted from acetylcholine and 8-bromo cyclic AMP stimulation (Haycock et al., 1982b). Two tryptic fragments of tyrosine hydroxylase were phosphorylated in untreated cells. Cyclic AMP phosphorylated one of these sites. Acetylcholine phosphorylated both sites. Vulliet et al. (1984) using HPLC analysis of tryptic fragments derived from purified tyrosine hydroxylase from rat pheochromocytoma demonstrated that cyclic AMPdependent protein kinase and $\mathrm{Ca}^{2+}$, calmodulin-dependent protein kinase each phosphorylates unique and different sites on a tyrosine hydroxylase subunit. The relationship between these analyses of tryptic fragment phosphorylation and the pattern of phosphorylation of the three subunits of tyrosine hydroxylase by forskolin (or dibutyryl cyclic AMP) and nicotinic agonist, observed in the present study, is unclear.

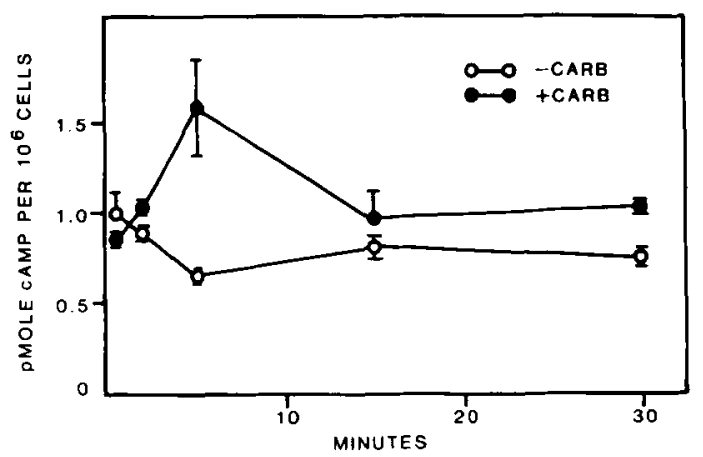

FIG. 13. Time course of carbachol-induced increase in cyclic AMP. Cells that were incubated in PSS with or without carbachol (carb) $(300 \mu M)$ for various times were analyzed for cyclic AMP. There were 2 samples per group. The means and the ranges of the values are shown.
TABLE 5. Carbachol-induced, $\mathrm{Ca}^{2+}$-dependent cyclic $A M P$ increase in chromaffin cells

\begin{tabular}{lc}
\hline \multicolumn{1}{c}{ Group } & $\begin{array}{c}\text { pmol cyclic AMP } \\
\text { per } 3 \times 10^{6} \text { cells }\end{array}$ \\
\hline 0 carbachol $/ 0 \mathrm{Ca}^{2+}$ & $4.00 \pm 0.11$ \\
$0.3 \mathrm{~m} M$ carbachol $/ 0 \mathrm{Ca}^{2+}$ & $3.60 \pm 0.01$ \\
$0 \mathrm{carbachol} / 2.2 \mathrm{~m} M \mathrm{Ca}^{2+}$ & $3.92 \pm 0.11$ \\
$0.3 \mathrm{mM}$ carbachol $/ 2.2 \mathrm{mM} \mathrm{Ca} \mathrm{Ca}^{2+}$ & $7.01 \pm 0.58^{4}$ \\
\hline
\end{tabular}

Cells were incubated in PSS containing $0 \mathrm{Ca}^{2+}$ and $1 \mathrm{mM}$ EGTA or $2.2 \mathrm{mM} \mathrm{Ca}{ }^{2+}$ and 0 EGTA for $15 \mathrm{~min}$. Intracellular cyclic AMP was measured after a 3-min incubation in the continuing presence or absence of $\mathrm{Ca}^{2+}$ with or without $0.3 \mathrm{mM}$ carbachol. There were three $60-\mathrm{mm}$ diameter dishes per group. ${ }^{a} \mathrm{p}<0.01$ versus 0 carbachol $/ \mathrm{Ca}^{2+}$

Niggli et al. (1984) recently demonstrated separate $\mathrm{Ca}^{2+}$ - and cyclic AMP-dependent systems for phosphorylation of tyrosine hydroxylase in suspended chromaffin cells with plasma membranes permeabilized by intense electric fields. Analysis of peptide fragments which were generated by protease from Streptomyces griseus revealed three sites of phosphorylation, all of which were phosphorylated by the $\mathrm{Ca}^{2+}$-dependent system. The cyclic AMP-dependent system phosphorylated two of the sites comparably with the $\mathrm{Ca}^{2+}$-dependent system but caused a smaller degree of phosphorylation of the third site. These data are consistent with our conclusions that (1) in situ $\mathrm{Ca}^{2+}$-dependent phosphorylation results in the formation of three subunits of tyrosine hydroxylase with different $\mathrm{pI}$ values and (2) in situ cyclic AMP-dependent phosphorylation results in formation of predominantly two of these subunits of tyrosine hydroxylase with relatively weak phosphorylation of the third subunit. Thus, phosphorylated subunits of tyrosine hydroxylase may have different pl values because of different sites of phosphorylation. It is also possible that the different $p I$ values of the subunits result from different numbers of phosphate groups/subunit.

Acknowledgment: We are grateful to Dr. A. W. Tank (Department of Pharmacology. University of Colorado Health Science Center, Denver, CO, U.S.A.) for the tyrosine hydroxylase antibody. We thank $\mathrm{C}$. E. Rothwell for initiating these experiments. The work was supported by PHS grant RO-1 AM27959 to RWH and NSF grant BNS 820799 to T.U. R. W. Holz is an Established Investigator of the American Heart Association.

\section{REFERENCES}

Albert K. A., Helmer-Matyjek E., Nairn A. C., Muller T. H., Haycock J. W. Greene L. A., Goldstein M., and Greengard P. (1984) Calcium/phospholipid-dependent protein kinase (protein kinase $C$ ) phosphorylates and activates tyrosine hydroxylase. Proc. Natl. Acad. Sci. USA 81, 7713-7717.

Amy C. M. and Kirshner N. (1981) Phosphorylation of adrenal medulla cell proteins in conjunction with stimulation of catecholamine secretion. J. Neurochem. 36, 847-854. 
Bradford M. M. (1976) A rapid and sensitive method for the quantitation of microgram quantitites of protein utilizing the principle of protein-dye binding. Anal. Biochem. 72, 248254.

Chalfie M. and Perlman R. L. (1977) Regulation of catecholamine biosynthesis in a transplantable rat pheochromocytoma. J. Pharmacol. Exp. Ther. 200, 588-596.

Cloutier G. and Weiner N. (1973) Further studies on the increased synthesis of norepinephrine during nerve stimulation of guinea pig vas deferens preparation: effect of tyrosine and 6,7-dimethyltetrahydropterin. J. Pharmacol. Exp. Ther. 186, 75-84.

Fisher S. K., Holz R. W., and Agranoff B. W. (1981) Muscarinic receptors in chromaffin cell cultures mediate enhanced phospholipid labeling but not catecholamine secretion. $J$. Neurochem. 37, 491-497.

Garrison J. C. and Wagner J. D. (1982) Glucagon and the $\mathrm{Ca}^{2+}$ linked hormones angiotensin II, norepinephrine, and vasopressin stimulate the phosphorylation of distinct substrates in intact hepatocytes. J. Biol. Chem. 257, 13135-13143.

Haycock J. W., Meligeni J. A., Bennett W. F., and Waymire J. C. (1982a) Phosphoryiation and activation of tyrosine hydroxylase mediate the acetylcholine-induced increase in catecholamine biosynthesis in adrenal chromaffin cells. J. Biol Chem. 257, 12641-12648.

Haycock J. W., Meligeni J. A., Bennett W. F., and Waymire J. C. (1982b) Multiple site phosphorylation of tyrosine hydroxlase. Differential regulation in situ by 8-bromo-cAMP and acetylcholine. J. Biol. Chem. 257, 13699-13703.

Holz R. W., Rothwell C. E., and Ueda T. (1980) Cholinergic agonist-stimulated phosphorylation of two specific proteins in bovine chromaffin cells: Correlation with catecholamine secretion. Soc. Neurosci. Abstr. 6, 177.

Holz R. W., Senter R. A., and Frye R. A. (1982) Relationship between $\mathrm{Ca}^{2+}$ uptake and catecholamine secretion in primary dissociation cultures of adrenal medulla. J. Neurochem. 39, 635-646.

Horwitz J. and Perlman R. L. (1984) Stimulation of DOPA synthesis in the superior cervical ganglion by veratridine. $J$. Neurochem. 42, 384-389.

Horwitz J., Tsymbalou S., and Perlman R. L. (1984) Muscarine increases tyrosine 3-monooxygenase activity and phospholipid metabolism in the superior cervical ganglion of the rat J. Pharmacol. Exp. Ther. 229, 577-582.

Joh T. H., Park D. H., and Reis D. J. (1978) Direct phosphorylation of brain tyrosine hydroxylase by cyclic AMP-dependent protein kinase: mechanism of enzyme activation. Proc. Natl. Acad. Sci. USA 75, 4744-4748.

Kilpatrick D. L., Slepetis R. J., Corcoran J. J., and Kirshner N. (1982) Calcium uptake and catecholamine secretion by cultured bovine adrenal medulla cells. $J$. Neurochem. 38, 427435.

Knight D. E. and Kesteven N. T. (1983) Evoked transient intracellular free $\mathrm{Ca}^{2+}$ changes and secretion in isolated bovine adrenal medullary cells. Proc. R. Soc. Lond. [Biol.] 218 , 177-179.

Meligeni J. A., Haycock, J. W., Bennett W. F., and Waymire J. C. (1982) Phosphorylation and activation of tyrosine hydroxylase mediate the cAMP-induced increase in catecholamine biosynthesis in adrenal chromaffin cells. J. Biol. Chem. 257, 12632-12640.

Nagatsu T., Levitt M., and Udenfriend S. (1964) Tyrosine hydroxylase. The initial step in norepinephrine biosynthesis J. Biol. Chem. 239, 2910-2917.

Niggli V., Knight D. E., Baker P. F., Vigny A., and Henry J.-P (1984) Tyrosine hydroxylase in "leaky" adrenal medullary cells: evidence for in situ phosphorylation by separate $\mathrm{Ca}^{2+}$ and cyclic AMP-dependent systems. J. Neurochem. 43, 646-658.

Nishizuka Y. (1984) Turnover of inositol phospholipids and signal transduction. Science 225, 1365-1370.

O'Farrell P. H. (1975) High resolution of two-dimensional electrophoresis of proteins. J. Biol. Chem. 250, 4007-4021.

Pocotte S. L. and Holz R. W. (1986) Effects of phorbol ester on tyrosine hydroxylase phosphorylation and activation in cultured bovine adrenal chromaffin cells. J. Biol. Chem. (in press).

Pocotte S. L., Frye R. A., Senter R. A., TerBush D. R., Lee S. A., and Holz R. W. (1985) Effects of phorbol ester on catecholamine secretion and protein phosphorylation in adrenal medullary cell cultures. Proc. Natl. Acad. Sci. USA 82, 930-934

Raese J. D., Edelman A. M., Lazar M. A., and Barchas J. D. (1977) Bovine striatal tyrosine hydroxylase: multiple forms and evidence for phosphorylation by cyclic AMP-dependent protein kinase, in Structure and Function of Monoamine Enzymes (Usdin E., Weiner N., and Youdim M. B. H., eds), pp. 383-400. Marcel Dekker, New York.

Towbin H., Staehelin T., and Gordon J. (1979) Electrophoretic transfer of proteins from polyacrylamide gels to nitrocellulose sheets: procedure and some applications. Proc. Natl. Acad. Sci. USA 76, 4350-4354.

Ueda T. and Greengard P. (1977) Adenosine $3^{\prime}, 5^{\prime}$-monophosphate-regulated phosphoprotein system of neuronal membranes. I. Solubilization, purification, and some properties of an endogenous phosphoprotein. J. Biol. Chem. 252, $5155-5163$

Ueda T., Maeno H., and Greengard P. (1973) Regulation of endogenous phosphorylation of specific proteins in synaptic membrane fractions from rat brain by adenosine $3^{\prime}: 5^{\prime}$-monophosphate. J. Biol. Chem. 248, 8295-8305.

Vulliet P. R., Langan T. A., and Weiner N. (1980) Tyrosine hydroxylase: a substrate of cyclic AMP-dependent protein kinase. Proc. Natl. Acad. Sci. USA 77, 92-96.

Vulliet P. R., Woodgett J. R., and Cohen P. (1984) Phosphorylation of tyrosine hydroxylase by calmodulin-dependent multiprotein kinase. J. Biol. Chem. 259, 13680-13683.

Wilson J. M., Daddona P. E., Simmonds H. A., VanAcker K. J., and Kelley W. N. (1982) Human adenine phosphoriboxyl transferase. Immunochemical quantitation and protein blot analysis of mutant forms of the enzyme. J. Biol. Chem. 257, $1508-1515$

Yamauchi T. and Fujisawa H. (1979) In vitro phosphorylation of bovine adrenal tyrosine hydroxylase by adenosine $3^{\prime}, 5^{\prime}$ monophosphate-dependent protein kinase. J. Biol. Chem. 254, 503-507.

Yamauchi T., Nakata H., and Fujisawa H. (1981) A new activator protein that activates tryptophan $S$-monooxygenase and tyrosine 3-monooxygenase in the presence of $\mathrm{Ca}^{2+}$, calmodulin-dependent protein kinase. J. Biol. Chem. 256, 54045409 .

Yanagihara N., Tank A. W., and Weiner N. (1983) Relationship between activation and phosphorylation of tyrosine hydroxylase by $56 \mathrm{mM} \mathrm{K}^{+}$and dibutryl cAMP in PC12 cells in culture. FASEB Abstr. 42, 501.

Yanagihara N., Tank A. W., and Weiner N. (1984) Relationship between activation and phosphorylation of tyrosine hydroxylase by $56 \mathrm{mM} \mathrm{K} \mathrm{K}^{+}$in PC12 cells in culture. Mol. Pharmacol. 26, 141-147. 